\title{
Learning by Debate: Innovative Tool in the Hematology-Oncology Fellowship Program
}

\author{
Ramy Samaha $^{1} \cdot$ Clarisse Kattan $^{1} \cdot$ Elie Rassy $^{1}$ (D) Joseph Kattan ${ }^{1}$ \\ Accepted: 24 March 2021 / Published online: 31 March 2021 \\ (C) American Association for Cancer Education 2021
}

\begin{abstract}
The knowledge base for medicine and medical education is continuously evolving, prominently medical oncology. These quick advances expose the oncologists to the pressing need to be up-to-date in their fields and complicate the oncology education of medical students and oncology fellows. As the international societies have developed new tools to help both practitioners and trainees stay abreast of the new advances, we have incorporated the debate teaching tool in our oncology fellowship program. A survey of the participants in the debate sessions over the last three years shows that fellows considered this teaching tool effective in consolidating and enriching their medical knowledge, enhancing their research and presentation skills, improving cognitive and communication skills as well as encouraging evidence-based learning.
\end{abstract}

Keywords Debate $\cdot$ Fellowship $\cdot$ Teaching tool $\cdot$ Program $\cdot$ Learning

\section{Introduction}

The Global Cancer Observatory (GLOBOCAN) data reported approximately 18 million new cancer cases in 2018 and 10 million yearly cancer deaths worldwide [1]. As the number of incident cases is projected to increase significantly by around $63 \%$ in 2040 , there is a rising demand to improve the quality of cancer care [1]. Considerable progress is being achieved technically and biologically with the advent of new diagnostic procedures and treatment strategies across the different medical specialties and particularly oncology. For instance, the Food and Drug Administration granted 64 approvals for new drugs or indications during 2020 [2]. These quick advances expose the oncologists to the pressing need to be up-to-date in their fields and complicate the acquisition of this knowledge base by trainees and students [3]. A joint Task Force from the European School of Medical Oncology (ESMO) and the American Society of Clinical Oncology (ASCO) produced the first outline for a Global Core Curriculum (GCC) for training in medical oncology back in 2004 and has published a more comprehensive and updated version in $2016[4,5]$. The curriculum of medical oncology at our institution embeded the GCC and was subject to the addition of oncology

Elie Rassy

elie.rassy@hotmail.com

1 Hematology and Oncology Department, Saint Joseph University, Beirut, Lebanon debate sessions where fellows take sides between pros and cons to develop their critical thinking and communication skills [6-10]. The debate teaching tool also creates a constructive learning environment of all learner levels by incorporating in-depth processing, critical analyses, inference, and judgment skills [11]. In this paper, we sought to share our three-year experience of learning by debate in the medical school of Saint Joseph University.

\section{Participants and methods}

We have incorporated the debate teaching tool in the oncology fellowship program by early 2016. It aimed to stimulate the oncology fellows to expand their learning process beyond passive reading to critical thinking and advanced clinical practice. The concept of the debate teaching tool was suggested by the senior author of this paper (JK) and approved by the academic board of the Saint Joseph University - Faculty of Medicine. The debates were conducted once every two months - sometimes more frequently - depending on the controversial topics that are raised by the newly published literature. Two oncology fellows were assigned to debate the topic after a preparation period of approximately three to four weeks during which they are coached by the attending physicians. These fellows were graded during the debate sessions by a jury of attending physicians (oncologists, radiotherapists, and pharmacists from our department, or invited physicians from other hospitals) to assess the comprehensive knowledge 
of the subject, the scientific content of the presentation, presentation layout, presentation skills, the structure of the presentation, argumentative competence, coherence and solidarity of the arguments, interaction with the audience, and respect of the assigned time. At the end of the debate, the jury discussed these skills and suggested constructive comments as appropriate. The audience included medical and pharmacy fellows, medical students, and oncology nurses.

Box 1: Example of the topics presented for debate between January 2016 and 2019

- Azacitidine is the best treatment for elderly patients with acute myeloid leukemia (2016).

- Immunomodulators are a mandatory maintenance therapy in patients with multiple myeloma (2016).

- The combination of nab-paclitaxel with platinum is the best first-line chemotherapy in advanced non-small cell lung cancer (2017).

- Lanreotide is the preferred treatment of neuroendocrine tumors (2017).

- Daratumumab is the preferred second-line treatment in multiple myeloma (2017).

- Ribociclib is the best CDK4/6 inhibitor in first-line therapy in luminal type metastatic breast cancer (2017).

- Nivolumab is the best treatment in second-line metastatic renal cell carcinoma (2018)

- Abiraterone-acetate plus androgen deprivation therapy is the preferred treatment for metastatic hormone-sensitive prostate cancer (2018).

- Ibrutinib is the preferred first-line treatment for patients with chronic lymphocytic leukemia (2018).

- Osimertinib is the preferred first-line treatment in EGFR alterations lung adenocarcinomas (2018).

- Lapatinib is the best second-line treatment in HER2+ positive metastatic breast cancer (2018).

We contacted, retrospectively, the fellows that participated in the debate to evaluate the usefulness of this tool as a teaching method. All fellows were contacted personally by e-mail to answer a 16-item questionnaire. The study procedure and the questionnaire were approved by our institutional ethical committee under the code CEHDF 1584.

\section{Results}

During the three-year period, 33 debate participants answered back the questionnaire. At the time of the questionnaire, the age range was between 25 and 35 years old of whom 14 (42.4\%) were still fellows at our institution, $6(18.2 \%)$ were fellows in European hospitals, and 13 (39.4\%) were newly graduates. Out of the 33 participants, $20(60.6 \%)$ participated as speakers and $13(39.4 \%)$ as audience attending. Among the 20 speakers, 5 (27.8\%) presented more than 4 times, 9 (50\%) between 2 and 4 times, and 4 (22.2\%) only once. The majority strongly agreed that the debate enhanced the communication and cognitive skill functions such as: assimilating information, constructing ideas, and formulating arguments (93.9 and $90.9 \%$, respectively), and encouraged evidence-based learning (97\%). It also improved research skills (87.9\%) and presentation skills $(84.8 \%)$. Last, $63.6 \%$ of the participants strongly agreed that this teaching tool is a better learning method compared to didactic lectures, and $83.9 \%$ favored recommending the debate technique as a learning tool (Fig. 1).

\section{Discussion}

Conventional teaching methods have been widely adopted in oncology fellowship programs. For instance, didactic tools are the mainstay of many international meetings such as the ESOESSO-ESTRO Multidisciplinary Course in Oncology [12] and the ESMO/ESO Masterclass in Clinical Oncology [13].

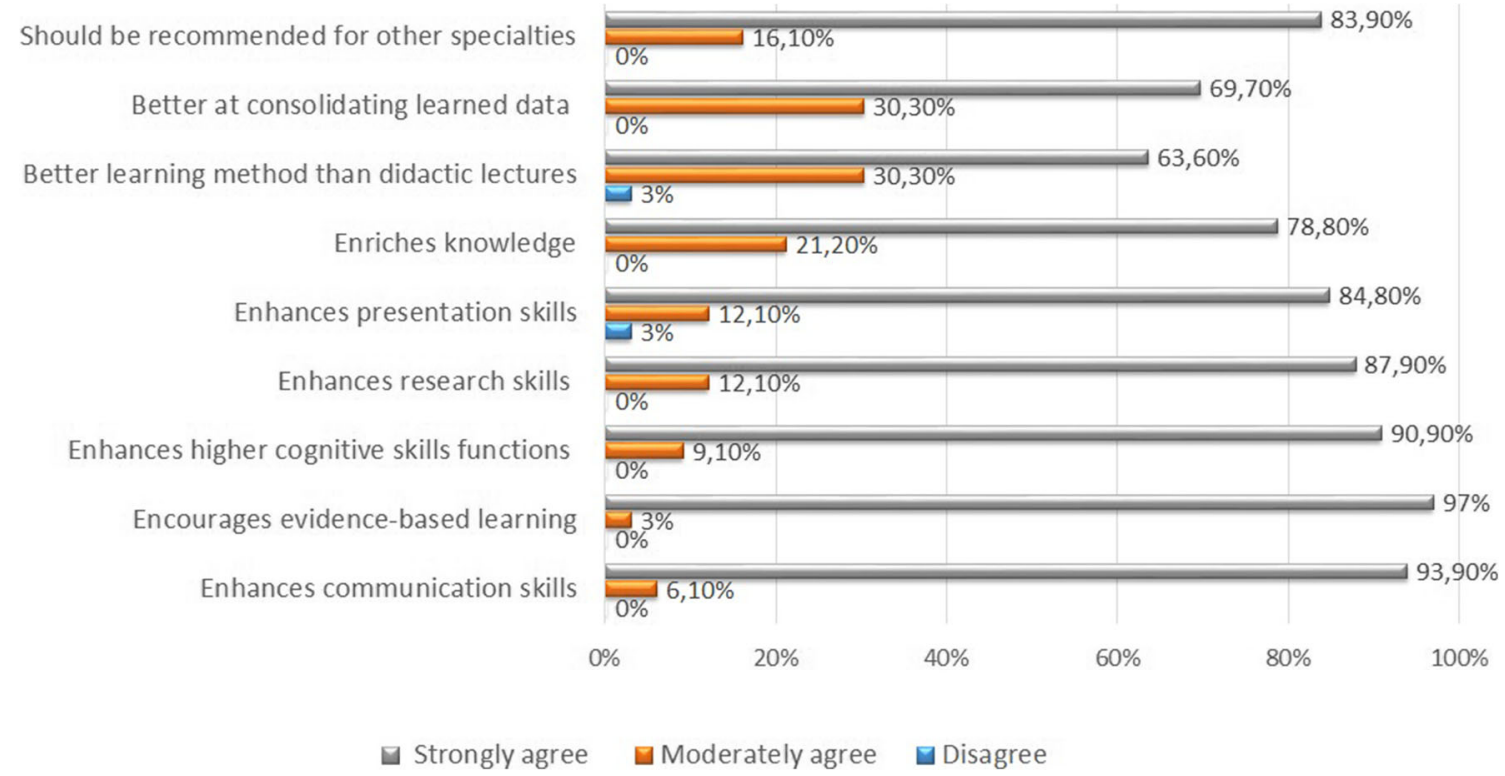

Fig. 1 Evaluation of the debate teaching tool 
Nevertheless, international societies have developed new tools to help both practitioners and trainees stay abreast of the new advances and increase the implications of fellows in their teaching. In this regard, the ESMO/ESO Masterclass in Clinical Oncology added many case presentations and discussions, the ESO recently launched the College of the European School of Oncology with direct guidance by international experts, and ASCO has developed the ASCO Journals Editorial Fellowship to initiate young graduates and fellows to the publication field. In line with publications in other fields, our experience shows that the fellow debates improve critical thinking and verbal communication [14].

The debate teaching tool has enabled the learning of skills and content within health professions education such as dentistry, pharmacy, medicine, nursing, and occupational therapy [15]. This tool of active learning is time-consuming but is more effective than didactic strategies [14]. Fellows that prepared and participated in debates were better at retaining information than those who attended a lecture (85.8 vs $61.7 \% ; p=0.003$ ) [16]. Moreover, fellows benefited from the input and feedback of experts from other disciplines such as the presence of urologists among the jury of urologic debate. The debate teaching tool may introduce young fellows to the publication field; in our experience, two topics coauthored by fellows and supervised by senior oncologists were published during the fellowship program [17, 18]. As such, the debate teaching tool contributed to the accomplishment of six core competencies recommended by the Accreditation Council for Graduate Medical Education: patient care, medical knowledge, practice-based learning and improvement, interpersonal and communication skills, professionalism, and systems-based practice [19]. We believe that using debate as a learning tool helps in the acquisition of all these skills and provides better training for future oncologists. Because of the COVID-19 pandemic, this teaching modality is being conducted through virtual meetings with the participation of four other oncology departments from local universities.

\section{Author Contribution Ramy Samaha: Review of literature, drafting and critical writing \\ Clarisse Kattan: Collection of data \\ Elie Rassy: Correction and critical writing \\ Joseph Kattan: Outline of the article, correction and final approval}

Funding The authors have no relevant affiliations or financial involvement with any organization or entity with a financial interest in or financial conflict with the subject matter or materials discussed in the manuscript. This includes employment, consultancies, honoraria, stock ownership or options, expert testimony, grants or patents received or pending, or royalties.

\section{Declarations}

Information Pertaining to Writing Assistance No writing assistance has been used in the creation of this manuscript.

Competing Interests The authors declare no competing interests.

\section{References}

1. The Global Cancer Observatory. https:/gco.iarc.fr/today/data/ factsheets/populations/900-world-fact-sheets.pdf.

2. Research $\mathrm{C}$ for DE and Hematology/Oncology (Cancer) Approvals \& Safety Notifications. FDA (2020).

3. Neeley BC, Golden DW, Brower JV, Braunstein SE, Hirsch AE, Mattes MD (2019) Student perspectives on oncology curricula at United States medical schools. J Cancer Educ Off J Am Assoc Cancer Educ 34(1):56-58

4. Hansen HH, Bajorin DF, Muss HB, Purkalne G, Schrijvers D, Stahel R (2004) Recommendations for a global core curriculum in medical oncology. Ann Oncol 15(11):1603-1612

5. Dittrich C, Kosty M, Jezdic S, Pyle D, Berardi R, Bergh J, el-Saghir N, Lotz JP, Österlund P, Pavlidis N, Purkalne G, Awada A, Banerjee S, Bhatia S, Bogaerts J, Buckner J, Cardoso F, Casali P, Chu E, Close JL, Coiffier B, Connolly R, Coupland S, de Petris L, de Santis M, de Vries EGE, Dizon DS, Duff J, Duska LR, Eniu A, Ernstoff M, Felip E, Fey MF, Gilbert J, Girard N, Glaudemans AWJM, Gopalan PK, Grothey A, Hahn SM, Hanna D, Herold C, Herrstedt J, Homicsko K, Jones DV Jr, Jost L, Keilholz U, Khan S, Kiss A, Köhne CH, Kunstfeld R, Lenz HJ, Lichtman S, Licitra L, Lion T, Litière S, Liu L, Loehrer PJ, Markham MJ, Markman B, Mayerhoefer M, Meran JG, Michielin O, Moser EC, Mountzios G, Moynihan T, Nielsen T, Ohe Y, Öberg K, Palumbo A, Peccatori FA, Pfeilstöcker M, Raut C, Remick SC, Robson M, Rutkowski P, Salgado R, Schapira L, Schernhammer E, Schlumberger M, Schmoll HJ, Schnipper L, Sessa C, Shapiro CL, Steele J, Sternberg CN, Stiefel F, Strasser F, Stupp R, Sullivan R, Tabernero J, Travado L, Verheij M, Voest E, Vokes E, von Roenn J, Weber JS, Wildiers H, Yarden Y (2016) ESMO / ASCO Recommendations for a global curriculum in medical oncology edition 2016. ESMO Open 1(5):e000097

6. Lieberman SA, Trumble JM, Smith ER (2000) The impact of structured student debates on critical thinking and informatics skills of second-year medical students. Acad Med J Assoc Am Med Coll 75(10 Suppl):S84-S86

7. Kennedy RR (2007) In-class debates: fertile ground for active learning and the cultivation of critical thinking and oral communication skills. International Journal of Teaching \& Learning in Higher Education 19(2)

8. Nguyen VQC, Hirsch MA (2011) Use of a policy debate to teach residents about health care reform. J Grad Med Educ 3(3):376-378

9. Jhaveri KD, Chawla A, Shah HH (2012) Case-based debates: an innovative teaching tool in nephrology education. Ren Fail 34(8): 1043-1045

10. Shah HH, Mattana J, Jhaveri KD (2013) Evidence-based nephrology-rheumatology debates: a novel educational experience during nephrology fellowship training. Ren Fail 35(6): 911-913

11. 'Site de l'Université Saint-Joseph de Beyrouth - USJ'. https://www. usj.edu.lb/fm/diplome.php?diplome=154\#.

12. Pavlidis N, Madry R, Peeters M, Sandrucci S, Markowska J, Peccatori F, Costa A, Eriksen JG, Ricardi U, Poetter R, Schrijvers D, Vermorken JB (2021) ESO-ESSO-ESTRO multidisciplinary course in oncology for medical students: 4 years of experience (2016-2019). J Cancer Educ. https://doi.org/10.1007/s13187-02001947-3

13. Pavlidis N, Peccatori F, Aapro M, Eniu A, Stahel R, Cervantes A, Cavalli F, Costa A (2019) ESO-ESMO masterclass in clinical oncology: analysis and evaluation of the learning self-assessment test. J Cancer Educ. https://doi.org/10.1007/s13187-019-01664-6

14. Garrett M, Schoener L, Hood L (1996) Debate: a teaching strategy to improve verbal communication and critical-thinking skills. Nurse Educ 21(4):37-40 
15. Ang RX, Chew QH, Sum MY, Sengupta S, Sim K (2019) Systematic review of the use of debates in health professions education - does it work? GMS J Med Educ 36(4)

16. Koklanaris N, MacKenzie AP, Fino ME, Arslan AA, Seubert DE (2008) Debate preparation/participation: an active, effective learning tool. Teach Learn Med 20(3):235-238

17. Rassy E, Abdayem P, Kattan J (2017) Circumvent hesitancy between CDK4/6 and mTOR inhibitors in second-line treatment of HR+, erb2- metastatic breast cancer. Future Oncol 13(17):14511453
18. Rassy E, Aoun F, Sleilaty G et al (2017) Network meta-analysis of second-line treatment in metastatic renal cell carcinoma: efficacy and safety. Future Oncol 13(29):2709-2717

19. 'ACGME core competencies - ECHO Resources'. https://www. ecfmg.org/echo/acgme-core-competencies.html.

Publisher's Note Springer Nature remains neutral with regard to jurisdictional claims in published maps and institutional affiliations. 